\title{
P05.73. A feasibility study of caregiver-provided massage for comfort care in Veterans with cancer
}

\author{
L Kozak $^{* *}$, E Vig $^{2}$, C Simons ${ }^{1}$, E Eugenio ${ }^{1}$, M Chapko ${ }^{1}$ \\ From International Research Congress on Integrative Medicine and Health 2012 \\ Portland, Oregon, USA. 15-18 May 2012
}

\section{Purpose}

The purpose of this study was to assess the feasibility of using a multimedia program to instruct caregivers in providing massage as supportive care for Veterans with cancer.

\section{Methods}

Dyads received a training program including DVD and manual, and were instructed to watch and practice at least 20 minutes/day over 8 weeks. The training program was specially developed for caregivers of cancer patients and previously tested in a randomized trial with non-veteran population. Feasibility assessed partner availability, perceived burden, clarity of instructional materials and compliance with training materials, weekly massage practice, and returning of data collection instruments.

\section{Results}

26 patient-caregiver dyads (92\% male patients and 95\% female caregivers) were recruited; $15 \%$ wanted to participate but did not have a partner. Only $11 / 26$ pairs, all of which were spouse dyads, completed the study, $38.5 \%$ of 26 recruited were unable to complete study because of being overwhelmed with caregiving activities. All patients were undergoing chemotherapy, radiation or both. For the $71.5 \%$ who completed 8 weeks, compliance with training materials was high (Mean times reading manual over 8 weeks $=15.83$ ). Dyads reported high satisfaction with training, 91\% declared training was very clear and easy to follow. Compliance with weekly practice was also high (Mean times caregiver provided massage over 8 weeks $=43.83)$. Compliance with data collection and returning of instruments was acceptable

${ }^{1}$ HSR\&D, VA Puget Sound Health Care System \& UW School of Public Health, Seattle, USA

Full list of author information is available at the end of the article for caregivers but poor for patients, who perceived forms as a burden.

\section{Conclusion}

Massage has been shown to support co-management of pain and anxiety in palliative care. Although massage is widely used at cancer centers around US, the VA system lacks occupational codes to hire LMPs to offer massage. This study showed feasibility of training caregivers of Veterans to provide simple massage for comfort care at home. Future studies should include a larger population and consider provision of caregiver support to facilitate adherence.

\section{Author details}

'HSR\&D, VA Puget Sound Health Care System \& UW School of Public Health, Seattle, USA. ${ }^{2}$ VA Puget Sound Health Care System, Seattle, USA.

Published: 12 June 2012

doi:10.1186/1472-6882-12-S1-P433

Cite this article as: Kozak et al:: P05.73. A feasibility study of caregiverprovided massage for comfort care in Veterans with cancer. BMC Complementary and Alternative Medicine 2012 12(Suppl 1):P433.

Submit your next manuscript to BioMed Central and take full advantage of:

- Convenient online submission

- Thorough peer review

- No space constraints or color figure charges

- Immediate publication on acceptance

- Inclusion in PubMed, CAS, Scopus and Google Scholar

- Research which is freely available for redistribution
C Biomed Central

C 2012 Kozak et al; licensee BioMed Central Ltd. This is an Open Access article distributed under the terms of the Creative Commons Attribution License (http://creativecommons.org/licenses/by/2.0), which permits unrestricted use, distribution, and reproduction in any medium, provided the original work is properly cited. 